\title{
SIMPLE AND SENSITIVE ENZYME-LINKED IMMUNOSORBENT ASSAY FOR IVERMECTIN
}

\author{
YOSHINORI MITSUI, HIDEAKI TANIMORI, TSUNEHIRO KITAGAWA, \\ YASUNORI FUIIMAKI, AND YOSHIKI AOKI \\ Department of Parasitology, Institute of Tropical Medicine, Nagasaki University, Sakamoto, \\ Nagasaki, Japan; Faculty of Pharmaceutical Sciences, Nagasaki University Bunkyou, Nagasaki, \\ Japan
}

\begin{abstract}
A sensitive and reproducible enzyme-linked immunosorbent assay (ELISA) for the determination of the concentration of ivermectin (IVM) in biological fluids was developed. A conjugate of IVM on bovine serum albumin and poly-L-lysine was used to produce antibodies in rabbits and served as a solid-phase marker for titration of antibodies, respectively. The competitive ELISA was conducted by simultaneously incubating IVM and IVM-biotin conjugate with anti-IVM antiserum over goat anti-rabbit IgG $(\mathrm{Fc})$ and then determining the amount of bound IVMbiotin with avidin-peroxidase conjugate as a tracer. The coefficient of variation for the assay was less than $10 \%$ in the range of $0.3-10 \mathrm{ng} / \mathrm{ml}$. The limit of detection was $0.1 \mathrm{ng} / \mathrm{ml}$. The cross-reactivities of anti-IVM antiserum with some anthelmintic drugs were negligible. Using this ELISA, serum levels of IVM were easily determined in Mongolian jirds (Meriones unguiculatus) up to $72 \mathrm{hr}$ following a single oral dose of $500 \mu \mathrm{g} / \mathrm{kg}$ of body weight.
\end{abstract}

Ivermectin (IVM), a macrocyclic lactone produced by an actinomycetes, Streptomyces avermitilis, is a potent new antiparasitic agent. It is active at extremely low doses against a wide variety of nematode and arthropod parasites. ${ }^{1} \mathrm{Re}$ cently, its antiparasitic potency against Onchocerca volvulus, Wuchereria bancrofti, and Brugia malayi has been tested in humans. ${ }^{2}$ Both in terms of clinical efficacy and side effects, IVM is becoming a microfilaricidal agent of first choice. ${ }^{2}$ As a prerequisite for studying the pharmacokinetics of IVM in humans, a method is needed for IVM analysis that is sufficiently sensitive to determine the concentration of IVM in biological fluids. Several high-performance liquid chromatography (HPLC) procedures have been reported for determining IVM in plasma. ${ }^{3-7}$ However, HPLC procedures necessitate time-consuming extractions and require a relatively large amount of blood, and thus are unsuitable for the routine screening of large numbers of samples or field use. Recently, Schmidt and others have produced monoclonal antibodies to IVM and developed an enzyme immunoassay as an alternative to HPLC for detecting IVM in agricultural and environmental samples. ${ }^{8}$ However, their assay system was not applied to the measurement of IVM in biological fluids of animals. We have investigated this approach further with the intent of devising a simple, sensitive enzyme-linked immunosorbent assay (ELISA) for detection of IVM in the blood of humans and animals. In this report, we describe 1) the production of anti-IVM antibodies in the rabbit, 2) the development of a competitive ELISA, and 3) the preliminary application of this immunoassay to the study of the pharmacokinetics of IVM in Mongolian jirds (Meriones unguiculatus).

\section{MATERIALS AND METHODS}

Materials. Ivermectin is an approximately 80:20 mixture of the 22,23-dihyrdoavermectin $B_{1 a}$ and $B_{1 b}$ (Figure 1). This compound was extracted with ether from Ivomec ${ }^{*}$, which was obtained from Shionogi Pharmaceutical Co., Ltd. (Osaka, Japan). Bovine serum albumin (BSA), porcine serum albumin (PSA) and poly-L-lysine hydrobromide (molecular weight $=45,000-87,000$ ) were obtained from Sigma Chem- ical Co. (St. Louis, MO). Goat anti-rabbit IgG peroxidase conjugate and goat anti-rabbit IgG (Fc) were obtained from Cappel Laboratories (West Chester, PA). Block Ace was obtained from Dainipon Pharmaceutical Co., Ltd. (Osaka, Japan). $N$-(2-aminoethyl) biotinamide was obtained from Vector Laboratories, Inc. (Burlingame, CA). All other chemicals or solvents were reagent grade or chemically pure.

Preparation of IVM-BSA conjugate used as an immunogen. The IVM was first converted to the nitrophenyl compound and conjugated with BSA as shown in Figure 1. Ivermectin (74 mg), triethylamine (34 mg), and 4-diethyl aminopyridine (34 $\mathrm{mg}$ ) were dissolved in $2 \mathrm{ml}$ of methylene chloride and cooled to $4^{\circ} \mathrm{C}$, then 4-nitrophenyl chloroformate ( $35 \mathrm{mg}$ ) dissolved in $0.5 \mathrm{ml}$ of methylene chloride was added and stirred for $1 \mathrm{hr}$ at $4^{\circ} \mathrm{C}$. Two milliliters of water was added to the above solution. The solution was extracted with ether, the extract was washed three times with water and dried over anhydrous sodium sulfate, the solvent was removed under vacuum, and the residue was purified by preparative thin-layer chromatography (TLC, silica gel 60F254, $20 \times 20 \mathrm{~cm}$ with a thickness of $0.5 \mathrm{~mm}$; E. Merck, Darmstadt, Germany) with tetrahydrofuran:chloroform (1:10) to obtain the nitrophenyl. compound ( $42 \mathrm{mg}, 48 \%$ yield). The nitrophenyl compound (12 mg) was dissolved in $0.5 \mathrm{ml}$ pyridine and slowly added to a solution of BSA $(25 \mathrm{mg})$ dissolved in $2.5 \mathrm{ml}$ of $10 \mathrm{mM}$ phosphate buffer (pH 7.4) and $2.0 \mathrm{ml}$ of pyridine at $4^{\circ} \mathrm{C}$. The mixture was stirred overnight at room temperature. The resulting BSA conjugate was di-

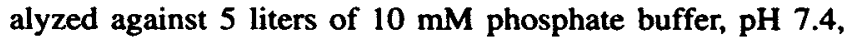
(five changes) for three days.

Preparation of IVM-poly-L-lysine conjugate used as a solid phase marker. The IVM-poly-L-lysine conjugate was prepared in a three-step procedure as shown in Figure 1. The 5-keto derivative of IVM was prepared according to the procedure of Fisher and Mrozik.9 Manganese dioxide (1.25 g) was added to a solution of IVM (350 mg) dissolved in $9 \mathrm{ml}$ of methylene chloride and stirred for $3 \mathrm{hr}$ at room temperature. The solution was filtered with filter paper and the solvent was removed under vacuum. Purification of the residue by preparative TLC with tetrahydrofuran:chloroform (1:5) gave 5-keto-IVM (284 mg, 72\% yield). 


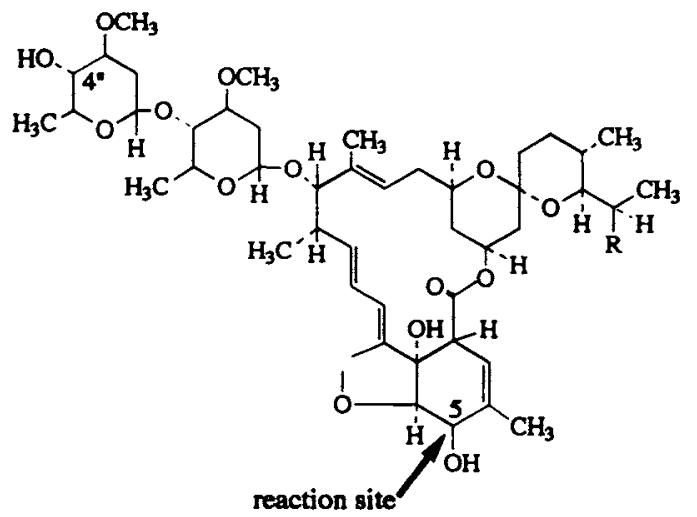

Structure of Ivermectin ( IVM)

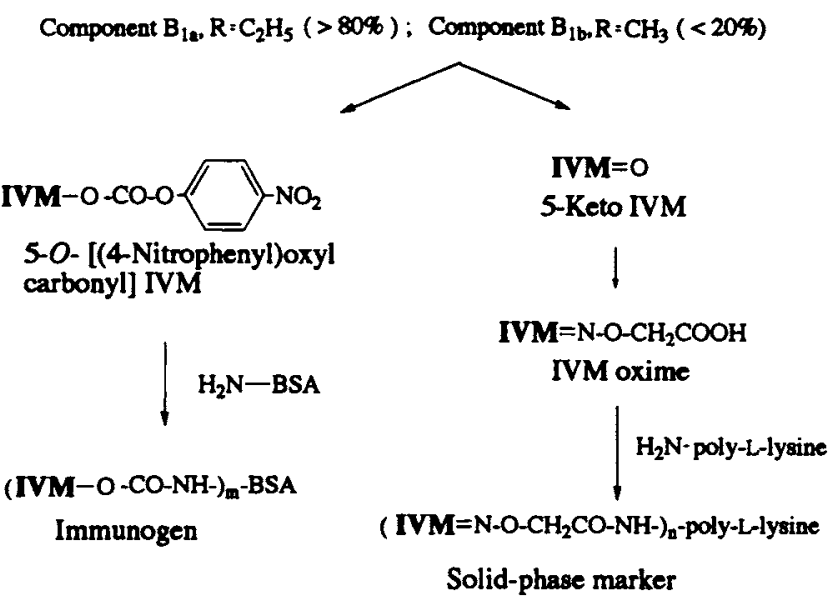

FIGURE 1. Preparation of the ivermectin-bovine serum albumin (IVM-BSA) conjugate used as the immunogen and IVM-poly-L-lysine conjugate used as a solid-phase marker.

Preparation of IVM oxime from the 5-keto IVM was carried out using the procedure of Zhang and others. ${ }^{10}$ In a typical experiment, a mixture of 5-keto IVM (180 mg), carboxymethoxylamine hemihydrochloride $(30 \mathrm{mg})$, and sodium acetate $(11 \mathrm{mg}$ ) were dissolved in $3 \mathrm{ml}$ of a solution of methanol:water (9:1) and stirred overnight at room temperature. The solvent was removed under vacuum and chloroform was added. The chloroform layer was washed three times with water and dried over anhydrous sodium sulfate and then concentrated to give IVM oxime $(50 \mathrm{mg}, 58 \%$ yield).

The IVM oxime was conjugated to poly-L-lysine by the modification of a method of Liu and others. " 1-ethyl-3 (3dimethylaminopropyl) carbodiimide hydrochloride $(1 \mathrm{mg}$ ) and $N$-hydroxysuccinimide $(1 \mathrm{mg}$ ) were added to the solution of IVM oxime $(5 \mathrm{mg})$ dissolved in $0.2 \mathrm{ml}$ of dimethylformamide (DMF), and then stirred for $30 \mathrm{~min}$ at room temperature. This solution was slowly added to poly-L-lysine hydrobromide $(5 \mathrm{mg})$ dissolved in $0.25 \mathrm{ml}$ of $0.13 \mathrm{M}$ $\mathrm{NaHCO}_{3}$ and stirred for $1.5 \mathrm{hr}$ at room temperature. The resulting conjugate was dialyzed against 3 liters of $0.1 \mathrm{M}$ $\mathrm{NaHCO}_{3}$ for two days. The solution of conjugate was adjusted to pH 5.5 with $1 \mathrm{~N} \mathrm{HCl}$ and centrifuged at $2,500 \mathrm{rpm}$ for $30 \mathrm{~min}$. The supernate was used as a solid-phase marker.

Preparation of IVM-biotin conjugate. The IVM-biotin conjugate was prepared using an $N$-hydroxysuccinintide es- ter method of Liu and others (Figure 2). ${ }^{11}$ Ivermectin oxime (1.5 $\mathrm{mg}), N$-hydroxysuccinintide $(0.2 \mathrm{mg})$, and dicyclohexyl carbodiimide $(0.35 \mathrm{mg})$ were dissolved in $50 \mu \mathrm{l}$ of DMF and incubated for $1 \mathrm{hr}$ at room temperature. The mixture was added to a solution of $N$-(2-aminoethyl)biotinamide $(0.7 \mathrm{mg})$ and triethylamin $(3 \mu \mathrm{l})$ in $200 \mu \mathrm{l}$ of DMF, stirred for two days at room temperature, and applied to a preparative TLC plate. The plate was developed in chloroform-methanol (3: 1). The IVM-biotin conjugate had an $R_{\mathrm{f}}$ value of 0.58 and was dissolved in $1 \mathrm{ml}$ of DMF and stored at $-30^{\circ} \mathrm{C}$ (stock IVM-biotin solution).

Immunization. A rabbit was injected both intradermally and intramuscularly with the IVM-BSA conjugate ( $1 \mathrm{mg}$ ) dissolved in $1 \mathrm{ml}$ of saline and emulsified with $1 \mathrm{ml}$ of Freund's complete adjuvant at sites on a shaved back area. For booster injection, the IVM-BSA conjugate $(0.5 \mathrm{mg})$ in $0.5 \mathrm{ml}$ of saline and $0.5 \mathrm{ml}$ of Freund's incomplete adjuvant was used. The repeated boosters were given on weeks 2,4 , 6 , and 8 after the initial injection. Blood samples were drawn via a marginal ear vein before immunization and $2,4,8$, and 12 weeks after initial injection with the IVM-BSA conjugate. The serum was stored at $-30^{\circ} \mathrm{C}$ until use.

Antibody titration by indirect ELISA. An indirect ELISA was used to detect antibodies. Wells of 96-well microtiter plates (\#655070; Dynatech Laboratories Inc., Chantilly, VA) were coated overnight at room temperature with $200 \mu$ l of 


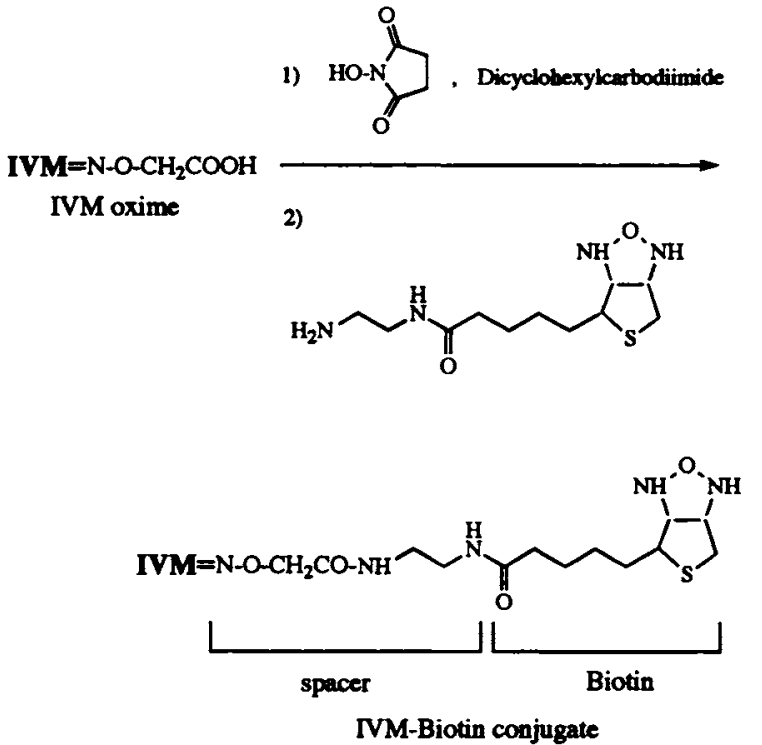

FIGURE 2. Preparation of the ivermectin (IVM)-biotin conjugate.

IVM-poly-L-lysine conjugate $(0.75 \mu \mathrm{g} / \mathrm{ml}$ in $0.1 \mathrm{M}$ sodium bicarbonate buffer, $\mathrm{pH}$ 9.6). The wells were washed three times with $300 \mu \mathrm{l}$ of phosphate-buffered saline (PBS, 10 $\mathrm{mM} \mathrm{Na} \mathrm{HPO}_{4}, 150 \mathrm{mM} \mathrm{NaCl}, \mathrm{pH} 7.4$ ) containing $0.05 \%$ [v/ v] Tween 20 (PBS-Tween). They were then blocked with $300 \mu \mathrm{l}$ of Block Ace diluted 1:5 in distilled water for 40 min at $37^{\circ} \mathrm{C}$ to prevent nonspecific absorption and washed two times with $300 \mu \mathrm{l}$ of PBS-Tween. Wells were incubated for $1 \mathrm{hr}$ at $37^{\circ} \mathrm{C}$ with $100 \mu \mathrm{l}$ of rabbit anti-IVM antiserum diluted serially in $0.1 \%$ BSA, PBS-Tween and $100 \mu \mathrm{l}$ of $1 \%$ PSA in $10 \mathrm{mM}$ phosphate buffer. The wells were washed five times with $300 \mu \mathrm{l}$ of PBS-Tween, incubated with 200 $\mu l$ of goat anti-rabbit IgG peroxidase conjugate diluted 1 : 1,500 in $0.1 \%$ BSA, PBS-Tween for $1 \mathrm{hr}$ at room temperature, washed three times with PBS-Tween, and incubated for $30 \mathrm{~min}$ at room temperature with $200 \mu \mathrm{l}$ of substrate solution ( $80 \mathrm{mM}$ citrate phosphate buffer, $\mathrm{pH}$ 5.0, $4.4 \mathrm{mM}$ 1,2-phenylene diamine, and $2 \mathrm{mM}$ hydrogen peroxide). The reaction was terminated by the addition of $100 \mu$ l of $0.2 \mathrm{M}$ sulfuric acid, and the absorbance at $492 \mathrm{~nm}$ was measured spectrophotometrically using an ELISA analyzer (Model ETY-96; Toyosoki Co. Ltd., Kanagawa, Japan).

Indirect competitive ELISA using IgG-peroxidase conjugate. The indirect competitive ELISA was identical to the antibody titration procedure except that $100 \mu \mathrm{l}$ of sample or IVM dissolved in $10 \%(\mathrm{v} / \mathrm{v})$ methanol in $1 \%$ PSA, PBSTween were simultaneously incubated for $2 \mathrm{hr}$ at $37^{\circ} \mathrm{C}$ with $100 \mu$ l of anti-IVM antiserum diluted $1: 2,000$ in $0.1 \%$ BSA, $10 \mathrm{mM}$ phosphate buffer. Bound antibody was measured as described in the antibody titration.

Competitive ELISA using IVM-biotin conjugate and avidin-peroxidase conjugate. Wells of 96-well microtiter plates (Nunc Immuno Plate MaxiSorp; Nunc, Roskilde, Denmark) were coated with $200 \mu \mathrm{l}$ of goat anti-rabbit IgG (Fc), (3.5 mg/L in 0.1 M sodium bicarbonate buffer, $\mathrm{pH}$ 9.6) for $2 \mathrm{hr}$ at $37^{\circ} \mathrm{C}$. The antiserum solution was removed and remaining binding sites were blocked by adding to each well $300 \mu \mathrm{l}$ of a $10 \mathrm{~g} / \mathrm{L} \mathrm{BSA}$ solution in distilled water containing

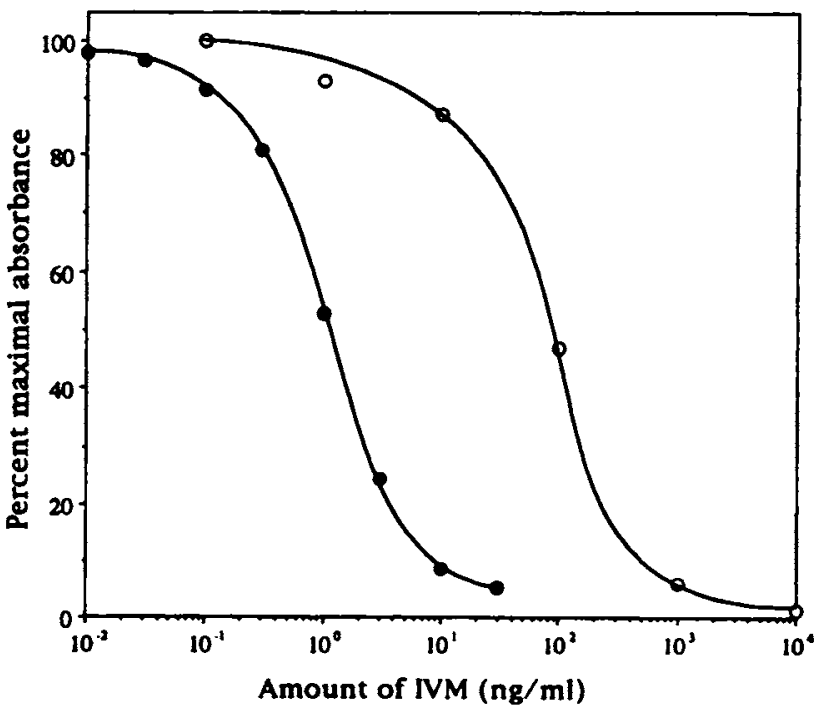

FIGURE 3. Standard curve of the competitive enzyme-linked immunosorbent assay for ivermectin (IVM). $O=$ using IgG peroxidase conjugate; $\bullet=$ using IVM-biotin conjugate and avidin peroxidase conjugate. Each point is the mean of four determinations.

$0.5 \mathrm{~g}$ of sodium azide per liter. After each well was washed with $300 \mu \mathrm{l}$ of PBS-Tween, $100 \mu \mathrm{l}$ of a standard of IVM or a blood sample diluted in $10 \mathrm{mM}$ phosphate buffer ( $\mathrm{pH} 7.4$ ) containing $0.1 \%$ BSA (phosphate buffer-BSA), $50 \mu \mathrm{l}$ of a 1: $2,000,000$ dilution of IVM-biotin stock in phosphate bufferBSA, and $50 \mu \mathrm{l}$ of a 1:20,000 dilution of anti-IVM antiserum in phosphate buffer-BSA were added to each well and the incubation was continued overnight at room temperature.

The wells were washed three times with $300 \mu$ l of PBSTween and reacted with $200 \mu \mathrm{l}$ of avidin-peroxidase diluted 1:7,000 in PBS-Tween for $1 \mathrm{hr}$ at room temperature. The wells were then washed four times with $300 \mu \mathrm{l}$ of PBSTween. To each well, $200 \mu \mathrm{l}$ of the substrate solution (pH

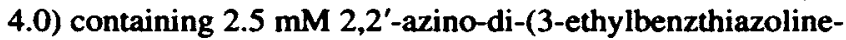
6-sulfonic acid) diammonium salt, $5.0 \mathrm{mM} \mathrm{\textrm {H } _ { 2 }} \mathrm{O}_{2}, 300 \mathrm{mM}$ citric acid, and $51 \mathrm{mM}$ disodium hydrogen phosphate per liter was added, and the color was allowed to develop in the dark for $\mathbf{4 0} \mathrm{min}$ at room temperature. One hundred microliters of sodium azide ( $1 \mathrm{~g} / \mathrm{L}$ in distilled water) was added to terminate the enzymatic reaction, and absorbances were measured at $405 \mathrm{~nm}$ with a microplate reader (Multiskan BICHROMATIC; Labsystems, Helsinki, Finland).

Determination of IVM concentrations in biological fiuids from a standard curve. A standard curve was constructed in every experiment in a range of $0.03-30 \mathrm{ng} / \mathrm{ml}$. It showed the percent maximal absorbance on the $y$-axis and the concentration of IVM on the $x$-axis. When the percent absorbance of sample to be tested was within the working range of the standard curve, the concentration of IVM in the sample was determined.

Determination of serum concentrations of IVM in jirds. Ivermectin was diluted 1:100 in ethanol:saline $(1: 3[\mathrm{v} /$ v]). Four male jirds weighing $104-106 \mathrm{~g}$ were given a single oral dose of IVM at $500 \mu \mathrm{g} / \mathrm{kg}$ of body weight. Blood from the retro-orbital sinus $(20 \mu \mathrm{l})$ was collected into tubes at 0 , $1,2,3,6,12,24$, and $72 \mathrm{hr}$ after administration of IVM. Blood was allowed to clot overnight at $4^{\circ} \mathrm{C}$ and then centri- 
TABLE 1

Cross-reactivity of anti-ivermectin (IVM) antiserum with IVM-related compounds and anthelmintics

\begin{tabular}{lc}
\hline Relative compound & $\begin{array}{c}\text { Cross-reactivity } \\
\text { (\% of IVM level) }\end{array}$ \\
\hline IVM & 100.0 \\
IVM oxime & 30.9 \\
Milbemycin & $<0.1$ \\
Erythromycin & $<0.01$ \\
Oleandmycin & $<0.01$ \\
Diethylcarbamazine & $<0.01$ \\
Praziquantel & $<0.01$ \\
\hline
\end{tabular}

fuged at 2,000 $\mathrm{tpm}$ for $15 \mathrm{~min}$. The serum was separated and stored at $-30^{\circ} \mathrm{C}$ until assayed. The pooled normal jird serum diluted 1:100 in phosphate buffer-BSA containing various concentrations of IVM was used for the construction of a standard curve for the determination of the IVM concentration in jird serum. The serum samples to be measured were first diluted 1:100 in phosphate buffer-BSA, and the concentration of IVM in the samples was then measured by the competitive ELISA using IVM-biotin.

\section{RESULTS}

Production of antibodies against IVM. An indirect ELISA was used to monitor the production of IVM antibodies in the rabbit. The serum samples taken at 6-12 weeks had a titer greater than 10,000 . The highest titer was detected at week 8 . Repeated booster injections after week 8 did not significantly increase IVM titers. Therefore, in the subsequent experiments, serum samples taken eight weeks after the initial immunization were used.

Competitive indirect ELISA using IgG-peroxidase conjugate. A typical IVM competitive ELISA dose-response curve is shown in Figure 3. The dose response range for this curve is between 10 and $1,000 \mathrm{ng} / \mathrm{ml}$.

Competitive ELISA using IVM-biotin and avidin-peroxidase conjugate. A typical IVM competitive ELISA doseresponse curve is shown in Figure 3. The dose-response range for this curve is between 0.1 and $10 \mathrm{ng} / \mathrm{ml}$. The sensitivity of the competitive ELISA using the IVM-biotin and avidin-peroxidase conjugates is 100 times as high as that of the ELISA using the IgG-peroxidase conjugate. Therefore, in subsequent experiments, the competitive ELISA was per- formed using the IVM-biotin and avidin-peroxidase conjugates.

Specificity. To ascertain the specificity of the rabbit antiIVM antiserum, the ability of the IVM derivative and some anthelminthic drugs to compete in the competitive ELISA was evaluated. The degree of cross-reaction of the test compounds with anti-IVM antiserum in terms of the percentage relative activity is shown in Table 1 . The relative activity was expressed as the amount of IVM to produce $50 \%$ binding of antibodies and IVM-biotin conjugate $\times 100 /$ the amount of test compounds to produce $50 \%$ binding of antibodies and IVM-biotin conjugate. The cross-reactivity of IVM oxime, a derivative of IVM, was $30.9 \%$, but those of all other drugs tested were less than $0.1 \%$.

Assay precision. The assay precision was examined at five different IVM levels over the range $0.1-10 \mathrm{ng} / \mathrm{ml}$ (Table 2). The recoveries of IVM added were satisfactory, and the coefficient of within assay variation was low. Therefore, the detection limit of the competitive ELISA using IVM-biotin and avidin-peroxidase conjugate is $0.1 \mathrm{ng} / \mathrm{ml}$.

Application of the method to biological samples. The present enzyme immunoassay was applied to monitor the serum concentration of IVM after a single oral dose (500 $\mu \mathrm{g} / \mathrm{kg}$ of body weight) to male jirds. Figure 4 shows the mean serum concentration-time profile of IVM after administration. The maximum serum concentration of $43.8 \mathrm{ng} / \mathrm{ml}$ was attained $2 \mathrm{hr}$ after administration. Thereafter, the serum level rapidly decreased, but interestingly, it again showed the high value $24 \mathrm{hr}$ after administration.

\section{DISCUSSION}

Ivermectin-protein conjugates have been formed and used as immunizing and screening antigen for the determination of IVM in biological fluids. ${ }^{8}$ We report here the successful preparation of IVM-BSA conjugates and production of antibodies to IVM in the rabbit. The immunogenicity of IVMprotein conjugates and the specificity of an antiserum for IVM are markedly influenced by the sites of the IVM molecule that are derivatized to couple with the carrier protein. In our study, the site of coupling of IVM with BSA was not defined exactly. However, the most probable site of coupling is at the C-5 position because the hydroxyl group of the allylic position is generally more reactive than the hydroxyl group at the $C^{\prime \prime}-4$ position.

TABLE 2

Precision of competitive enzyme-linked immunosorbent assay using ivermectin (IVM)-biotin conjugate and avidin-peroxidase conjugate

\begin{tabular}{|c|c|c|c|c|c|}
\hline Sample & $\begin{array}{c}\text { IVM added } \\
(\mathrm{ng} / \mathrm{ml})\end{array}$ & $\begin{array}{l}\text { Estimated } \\
(\mathrm{ng} / \mathrm{m})\end{array}$ & $\begin{array}{c}\text { Recovery } \\
\text { (\%) }\end{array}$ & $\begin{array}{l}\text { Percent coefficient } \\
\text { of variation }(\%)\end{array}$ & Number of assays \\
\hline \multirow[t]{5}{*}{ Intra-assay } & 0.1 & $0.098 \pm 0.018$ & 98.0 & 18.1 & 6 \\
\hline & 0.3 & $0.298 \pm 0.028$ & 99.3 & 9.5 & 6 \\
\hline & 1.0 & $0.992 \pm 0.031$ & 99.2 & 3.2 & 6 \\
\hline & 3.0 & $3.02 \pm 0.02$ & 101.0 & 0.8 & 6 \\
\hline & 10.0 & $10.01 \pm 0.53$ & 100.0 & 5.3 & 6 \\
\hline \multirow[t]{5}{*}{ Interassay } & 0.1 & $0.098 \pm 0.008$ & 98.0 & 7.9 & 6 \\
\hline & 0.3 & $0.306 \pm 0.016$ & 102.0 & 5.3 & 6 \\
\hline & 1.0 & $1.007 \pm 0.009$ & 100.7 & 0.9 & 6 \\
\hline & 3.0 & $3.01 \pm 0.07$ & 100.2 & 2.2 & 6 \\
\hline & 10.0 & $10.24 \pm 0.28$ & 102.4 & 2.7 & 6 \\
\hline
\end{tabular}

\footnotetext{
* Values are the mean \pm SD
} 


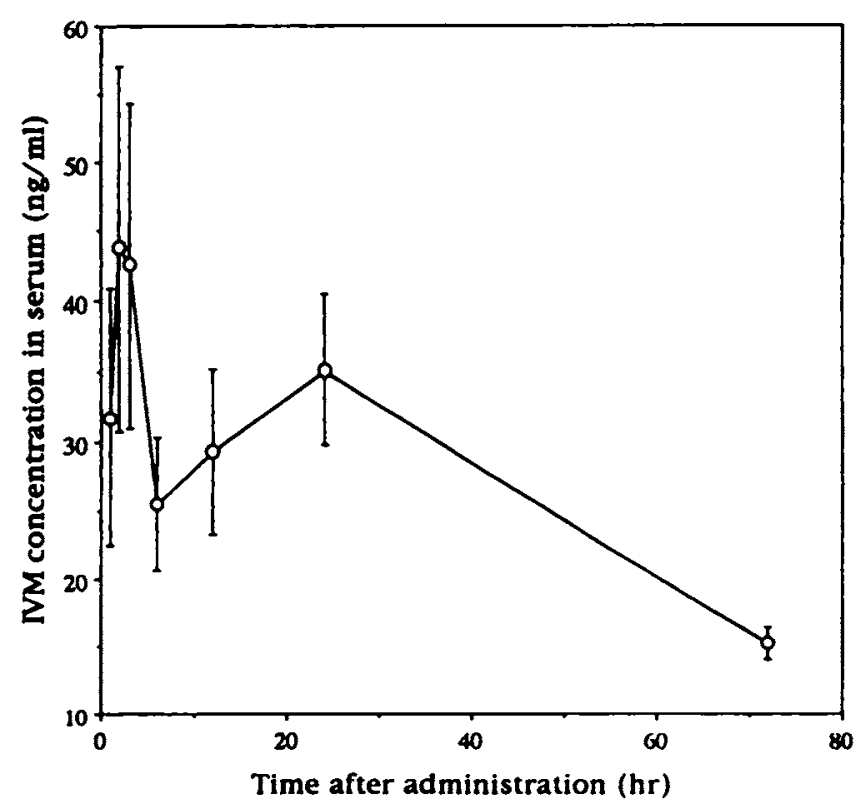

FIGURE 4. Serum concentration of ivermectin (IVM) in jirds following a single oral administration $(500 \mu \mathrm{g} / \mathrm{kg})$. Each point represents the mean $\pm S E$ for five animals.

The IVM oxime-poly-L-lysine conjugate as a solid-phase marker was prepared by the use of carbomethoxyloxime as a cross-linker in consideration of the fact it might avoid a cross-reaction with the antibody produced against the immunogen linkage group of carboxycarbonyl. We tested a classical competitive ELISA using anti-IVM antibodies and IVM-poly-L-lysine conjugate as a solid phase marker. The detection limit of this assay was $10 \mathrm{ng} / \mathrm{ml}$ in the buffer system used. To develop a more sensitive enzyme immunoassay for IVM, we investigated some other configurations including IVM-biotin. Among them, the configuration using IVMbiotin and avidin peroxidase gave the highest sensitivity $(0.1$ $\mathrm{ng} / \mathrm{ml}$ in buffer). This assay probably enables IVM and IVM-biotin to compete successfully for antibody due to the small molecular weight of biotin. It is also possible that the enzyme reaction is amplified by biotin-avidin system due to high-affinity binding between biotin and avidin. The detection limit of our method is 5-10-fold lower than those of the HPLC procedures ${ }^{3-7}$ and that of a competitive enzyme immunoassay using monoclonal antibody to IVM. ${ }^{8}$

The cross-reactivity of the IVM antibodies with some anthelminthic drugs was negligible. Recently, it had been confidently expected that the combination of IVM and diethylcarbamazine (DEC) would be effective for the treatment of lymphatic filariasis. ${ }^{12}$ Our competitive ELISA will be useful for the evaluation of the efficacy of the combination of IVM and DEC.

The competitive ELISA we describe here was usable for the accurate detection of IVM in serum without interference from endogenous or exogenous substances in rodents blood when the serum sample was diluted 1:100 in buffer. By direct dilution of serum in assay buffer, our assay can detect concentration as little as $10 \mathrm{ng} / \mathrm{ml}$ of IVM in $2-5-\mu 1$ serum samples. The actual detection limit in serum was 100 times higher than that in buffer because of the dilution factor of serum. This assay should be applicable to any other biological fluids.

Recently, a Brugia pahangi-jird model has been widely used for primary screening of anti-filarial drugs. ${ }^{2}$ However, no pharmacokinetic study of IVM in jirds has been done. Therefore, we attempted to measure IVM concentration in these animals. Our method successfully determined the serum concentration-time profiles of IVM in jirds up to $72 \mathrm{hr}$ after administration of IVM. The serum concentration-time profiles of our pilot study, however, are different from those reported by Schnitzerling and Nolan,, Kojima and Yamamoto, ${ }^{4}$ and Krishna and Klotz. ${ }^{7}$ They reported a monoexponential decrease in the plasma level of IVM following the peak concentrations in cows, dogs, and humans. There are three possible explanations for the appearance of two peaks after oral administration of IVM to jirds. First, IVM is insoluble in water. Therefore, there was considerable variation in the absorption of IVM in the intestine of the jirds. If this was the case, the individual variation in the peak time after oral administration should be more prominent. Second, IVM is metabolized to products that influence the assay system. This is also very unlikely because the anti-IVM antibodies we used are relatively specific for IVM and IVM is reported to be excreted mainly in the feces in an unchanged form.' Third, IVM undergoes enterohepatic circulation (EHC). Drugs that undergo EHC, e.g., the steroids, show two peaks in the serum concentration-time profiles that are similar to the two peaks observed in this study. ${ }^{13}$ Interestingly, EHC of IVM in the salmon has been reported, ${ }^{14}$ and Edwards and others reported that IVM was excreted into the bile in mice. ${ }^{15}$ Thus, the third explanation is not unlikely. Further studies will be needed to explain the appearance of two peaks in concentration-time profile of IVM in jirds.

The concentration of IVM in the blood has been determined by HPLC. However, HPLC procedures are time-consuming, require large amounts of blood, and are unsuitable for routine screening of large numbers of samples or field use. We have developed a simple, sensitive, and reproducible competitive ELISA for the determination of IVM in biological fluids. Our method requires only $5 \mu \mathrm{l}$ of serum for triplicate determinations with a detection limit of $10 \mathrm{ng} / \mathrm{ml}$ in serum. This assay can be used for monitoring plasma levels of IVM in clinical studies for evaluating its optimal dosage regimen and pharmacokinetics of IVM in humans and experimental animals.

Financial support: This work was partially supported by grants-inaid (no. 04557023 and no. 06770188) for Scientific Research from the Ministry of Education, Science and Culture of Japan.

Authors' addresses: Yoshinori Mitsui, Yasunori Fujimaki, and Yoshiki Aoki, Department of Parasitology, Institute of Tropical Medicine, Nagasaki University, 1-12-4 Sakamoto, Nagasaki 852, Japan. Hideaki Tanimori and Tsunehiro Kitagawa, Faculty of Pharmaceutical Sciences, Nagasaki University, 1-14 Bunkyoumachi, Nagasaki 852, Japan.

Reprint requests: Yoshinori Mitsui, Department of Parasitology, Institute of Tropical Medicine, Nagasaki University, 1-12-4 Sakamoto, Nagasaki 852, Japan.

\section{REFERENCES}

1. Campell WC, Fisher MH, Stapley EO, Albers-Schonberg G, Jacob TA, 1983. Ivermectin; a potent new antiparasitic agent. Science 221: 823-828. 
2. World Health Organization, 1991. Tropical Diseases, Progress in Research 1989-1990. Tenth Program Report of UNDP/ World Bank/WHO Special Programme for Research and Training in Tropical Diseases. Geneva: World Health Organization.

3. Shnitzerling HJ, Nolan J, 1985. Normal phase liquid chromatographic determination of nanogram quantities of ivermectin in cattle blood or plasma. J Assoc Off Anal Chem 68: 36-40.

4. Kojima K, Yamamoto K, 1987. Determination of 22,23-dihydro-avermectin $B_{1,}$ in dog plasma using solid-phase extraction and high-performance liquid chromatography. J Chromatogr 413: 326-331.

5. Pivnichny JV, Lawrence AA, Stong JD, 1987. A robotic sample preparation scheme for the high performance liquid chromatographic determination ivermectin in animal plasma. $J$ Chromatogr Sci 25: 181-186.

6. Oehler DD, Miller JA, 1989. Liquid chromatographic determination of ivermectin in bovine serum. J Assoc Off Anal Chem 72: 59.

7. Krishna DR, Klotz U, 1993. Determination of ivermectin in human plasma by high-performance liquid chromatography. Arzeim-Forsch/Drug Res 43: 609-611.

8. Schmidt DJ, Clarkson CE, Swanson TA, Egger ML, Carlson RE, Van Emon JM, Karu AE, 1990. Monoclonal antibodies for immunoassay of avermectins. J Agric Food Chem 38: $1763-1770$.

9. Fisher MH, Mrozik M, 1984. Avermectin family of macrolidelike antibiotics. Omura S, ed. Macrolide Antibiotics. New York: Academic Press, 553-606.

10. Zhang GS, Schubring SL, Chu FS, 1986. Improved method for production of antibodies against T-2 toxin and diacetoxyscirpenol in rabbits. Appl Environ Microbiol 51: 132-137.

11. Liu MT, Ram BP, Hart LP, Pestka JJ, 1985. Indirect enzymelinked immunosorbent assay for the mycotoxin zearalenoe. Appl Environ Microbiol 50: 332-336.

12. Moulia-Pelat JP, Nguyen LN, Glaziou P, Chanteau S, Ottesen EA, Chardines R, Martin PMV, Cartel JL, 1994. Ivermectin plus diethylcarbamazine: an additive effect on early microfilarial clearance. Am J Trop Med Hyg S0: 206-209.

13. Schumann W, Hillesheim HG, Gira G, 1986. Model systems for pharmacokinetics of steroid drugs subject to enterohepatic circulation. Exp Clin Endocrinol 87: 118-124.

14. Hoy T, Horsberg TE, Nafstad I, 1990. The disposition of ivermectin in Atlantic salmon (Salmo salar). Pharmacol Toxicol 67: 307-312.

15. Edwards G, Dingsdale A, Orme M, Brekenridge A, 1989. Tissue distribution and excretion of $[3 \mathrm{H}]$ ivermectin in the mouse. Trop Med Parasitol 40: 83. 